VOL. $15(1976), 154$.

\title{
The organisation of passenger transport in urban areas
}

\section{Elizabeth Anne Cousins}

By the use of the continuum approach to Transportation Theory, this thesis seeks to examine the effect of various transportation schemes on travel times and distances. The fuel crisis of the 1970's, the continuing suburban growth of cities, and the ineffectiveness of conventional road systems and public transport services have all contributed to the need for a re-evaluation of transport trends.

The main proposals discussed in this thesis are:

(i) carpools and demand-responsive systems, as a means of increasing the average occupancy rates of vehicles, thereby decreasing the number of automobiles using the roads for work journeys, and hence, reducing vehicle kilometres and total fuel consumption;

(ii) a park-and-ride scheme, coupled. with a pedestrian precinct. Private automobiles are eliminated from the area which usually experiences the greatest congestion (the Central Business District), but an efficient, frequent bus service caters for the needs of commuters.

Various models are used to describe the distribution of homes and workplaces throughout the city, results being compared where possible.

Received 15 April 1976. Thesis submitted to the University of Newcastle, New South Wales, November 1975. Degree approved, April 1976. Supervisor: $\mathrm{Dr}$ R.J. Vaughan. 